\title{
Changes to the Statutes and Subcommittees of the International Committee on Taxonomy of Viruses (2014)
}

\author{
M. J. Adams $\cdot$ E. B. Carstens
}

Received: 29 April 2014/ Accepted: 30 May 2014/Published online: 7 June 2014

(C) Springer-Verlag Wien 2014

Following discussions at the Executive Committee meeting of the International Committee on Taxonomy of Viruses (ICTV) in Edinburgh, UK, in July 2013, it was agreed to propose changes to the Statutes to allow the appointment of a third Secretary, with particular responsibility for virus data. These changes have now been formally adopted, following approval by the ICTV voting membership (in a ballot conducted by e-mail) and by IUMS Virology Division, as required by the Statutes.

The composition of the Executive Committee of ICTV consists of (I) the Officers of ICTV, namely President, Vice-President and Secretaries, (II) the Chairs of the six Executive Committee Subcommittees and (III) eight elected Members. Until now one of the Subcommittees has been responsible for virus data, but this historic arrangement no longer best serves current needs. In particular, it does not provide sufficient continuity for managing the internet web site (http://www.ictvonline.org) and the related discussion site (http://talk.ictvonline.org/) that now support all ICTV operations. These web sites (1) provide the latest virus taxonomy to the public in accessible form; (2) are essential for submission and management of taxonomic proposals under discussion (providing opportunity for public comment); (3) act as an archive for all past taxonomic decisions; and (4) act as the public face of ICTV with information about its organization and membership, as well as listing and acknowledging the participation of the

M. J. Adams ( $\square)$

24 Woodland Way, Stevenage, Herts SG2 8BT, UK

e-mail: mike.adams.ictv@gmail.com

\section{E. B. Carstens}

Department of Biomedical and Molecular Sciences,

Queen's University, Kingston, ON K7L 3N6, Canada

e-mail: carstens@queensu.ca many specialist members of the various Study Groups. Most importantly for the future, it is now intended that the ICTV Report will be prepared and presented in an online format managed by ICTV itself. Because of the importance of all these activities, ICTV has decided that it would be best to assign the day-to-day management of all these activities to a specific ICTV Secretary, a position that will have a 6-year term that is renewable for a second term. The two existing Secretaries remain responsible for the processing and tracking of taxonomic proposals and for the administration of ICTV business. Six Subcommittees are being retained to help manage the increasing volume of taxonomic proposals, but their remits will change. Three Subcommittees will now share responsibility for viruses of vertebrates and invertebrates, divided according to their genome types (DNA, ssRNA- and ssRNA+). The other three Subcommittees are not affected by these changes; they will continue to be responsible for (1) viruses of plants, (2) viruses of fungi, algae and protists, and (3) viruses of prokaryotes and archaea.

These changes in the composition of the ICTV Executive Committee will be implemented by appointments to be made at the ICTV plenary session at the International Congress of Virology in Montreal, Canada, in July 2014. As a result, the size of the Executive Committee will increase from 18 to 19 members.

The changes made to the Statutes in 2014 are:

Section 4.2 (final sentence): the statement 'and that one subcommittee is responsible for virus data' is omitted.

Section 4.3 (B) begins 'Three ...' rather than 'Two ...'

Section 9.3 (Duties of the Secretaries): two subsections have been added:

E. To manage the submission and processing of taxonomic proposals. 
F. To maintain the ICTV web site and databases that provide up-to-date taxonomic information, information on ICTV activities and membership, the ICTV Report and other outreach activities.
The text of the complete ICTV Statutes (2014) may be obtained at http://www.ictvonline.org/statutes.asp. 